\title{
Pain catastrophizing scale for francophone adolescents: A preliminary validation
}

\author{
Isabelle Tremblay BSc ${ }^{1}$, Yves Beaulieu PhD ${ }^{2}$, Annie Bernier $\mathrm{PhD}^{1}$, Geert Crombez $\mathrm{PhD}^{3}$, Simon Laliberté PhD ${ }^{4}$, \\ Pascal Thibault BSc ${ }^{5}$, Ana M Velly DDS $\mathrm{PhD}^{6}$, Michael JL Sullivan $\mathrm{PhD}^{5}$
}

\begin{abstract}
I Tremblay, Y Beaulieu, A Bernier, et al. Pain catastrophizing scale for francophone adolescents: A preliminary validation. Pain Res Manage 2008;13(1):19-24.
\end{abstract}

BACKGROUND: In adults, it is well known that high levels of pain catastrophizing are related to increased pain and disability as well as to heightened anxiety and depression. However, due to the lack of a measure of pain catastrophizing adapted for francophone adolescents, little is known about the role of catastrophizing in this population.

OBJECTIVES: To adapt the French version of the Pain Catastrophizing Scale (PCS) and to examine the psychometric properties and factorial structure of the PCS for Francophone Adolescents (PCS-Ado).

METHODS: The French version of the PCS was modified by a group of experts. The format of the questions was modified to be appropriate for adolescents aged between 12 and 18 years. To assess the psychometric properties of the PCS-Ado, 345 adolescents completed the PCS-Ado and questionnaires measuring depression, anxiety and intensity of pain. Twelve to 16 weeks later, participants completed the questionnaires again to examine the test-retest reliability of the PCS-Ado.

RESULTS: Results revealed a three-factor solution similar to the original PCS. In addition, results revealed that PCS-Ado had good internal consistency (PCS-Ado total: 0.85; rumination: 0.72; magnification: 0.66; helplessness: 0.74), and high test-retest reliability $(\mathrm{r}=0.73)$. Finally, significant correlations among catastrophizing, depression, anxiety and pain intensity support the construct validity of the PCS-Ado.

CONCLUSIONS: The results suggest that the PCS-Ado is valid and reliable with francophone adolescents. Further research is required to assess the validity of the PCS-Ado in clinical settings.

Key Words: Adolescents; Pain; Pain catastrophizing scale; Psychometric properties

$\mathrm{D}$ uring the past decade, numerous investigations have revealed that acute, recurrent and chronic pain are prevalent in pediatric populations (1). For example, McGrath et al (2) showed that all children between five and 15 years of age reported experiencing acute pain during the last month (2). In addition, it has been shown that $7 \%$ to $25 \%$ of school children and adolescents report recurrent abdominal pain (3-10), and $15 \%$ to $22 \%$ of children and adolescents report recurrent headaches $(2,11)$. Approximately 25\% of adolescents report musculoskeletal pain (eg, low back pain, knee pain) at least

\section{Échelle de dramatisation de la douleur adaptée aux adolescents francophones : validation préliminaire}

CONTEXTE : C'est bien connu, un degré élevé de dramatisation de la douleur chez les adultes est lié à une augmentation de la douleur et de l'incapacité ainsi qu'à une augmentation de l'anxiété et de la dépression. Cependant, comme il n'existe pas de mesure suffisante de la dramatisation de la douleur, adaptée aux adolescents francophones, on en sait peu sur le rôle du phénomène dans ce segment particulier de la population.

BUTS : L'étude avait pour buts d'adapter la version française de l'échelle Pain Catastrophizing Scale (PCS) et d'examiner les propriétés psychométriques et la structure factorielle de la PCS chez des adolescents francophones (PCS-Ado).

MÉTHODE : La version française de la Pain Catastrophizing Scale a été modifiée par un groupe de spécialistes. Les questions ont été reformulées de manière à correspondre au vocabulaire des adolescents âgés de 12 à 18 ans. Afin d'évaluer les propriétés psychométriques de la PCS-Ado, nous avons demandé à 345 adolescents de remplir l'échelle PCS-Ado et les questionnaires visant à mesurer la dépression, l'anxiété et l'intensité de la douleur. Les participants ont répondu de nouveau aux questionnaires, de 12 à 16 semaines plus tard, afin que soit vérifiée la fiabilité test-retest de la PCS-Ado.

RÉSULTATS : Les résultats ont révélé une solution trifactorielle comparable à celle de la version originale de la PCS. De plus, ils ont montré que la PCS-Ado avait une bonne cohérence interne (PCS-Ado : total =0,85; rumination $=0,72$; exagération $=0,66$; sentiment d'impuissance $=0,74$ ) et une bonne fiabilité test-retest $(\mathrm{r}=0,73)$. Enfin, la forte corrélation entre la dramatisation et la dépression, l'anxiété et l'intensité de la douleur confirme la validité du construct de la PCS-Ado.

CONCLUSIONS : Les résultats semblent indiquer que la PCS-Ado est valide et fiable chez les adolescents francophones. Il reste maintenant à en évaluer la validité en pratique clinique.

once a week (12-14) and approximately $20 \%$ of adolescents report chronic pain $(3,15,16)$.

Pain in children and adolescents can contribute to significant adverse social, familial and personal consequences $(17,18)$. For example, when compared with normal populations, children and adolescents suffering recurrent and chronic pain miss more school days and report higher levels of depression, anxiety and sleep disorders (19-27). Pain experienced by adolescents is also related to lower quality of life in the family (28).

${ }^{1}$ Department of Psychology, University of Montreal; ${ }^{2}$ Department of Psychology, Montreal Children's Hospital, Montreal, Quebec; ${ }^{3}$ Department of Experimental-Clinical and Health Psychology, Ghent University, Belgium; ${ }^{4}$ Centre de réadaptation Lucie-Bruneau; ${ }^{5}$ Department of Psychology, McGill University, Montreal, Quebec; ${ }^{6}$ Division of TMD and Orofacial Pain, Department of Diagnostic and Biological Sciences, University of Minnesota, Minneapolis, Minnesota, USA

Correspondence: Dr Michael JL Sullivan, Department of Psychology, McGill University, 1205 Docteur Penfield, Montreal, Quebec H3A 1 B1.

Telephone 514-398-5677, fax 514-398-4896, e-mail michael.sullivan@mcgill.ca. 
In adults, children and adolescents suffering acute or persisting pain, it has been shown that pain catastrophizing is one of the most robust predictors of heightened pain, disability and emotional distress. Sullivan et al (29) characterized pain catastrophizing as an "exaggerated negative 'mental set' brought to bear during actual or anticipated pain experience". Sullivan et al (30) developed the Pain Catastrophizing Scale (PCS) to assess three dimensions of catastrophizing; namely, magnification (eg, I wonder whether something serious may happen); rumination (eg, I keep thinking about how badly I want the pain to stop); and helplessness (eg, It's terrible and I think it's never going to get any better). The PCS proved to be a useful tool for assessing pain catastrophizing in adults, as well as in children and adolescents. Numerous investigations have shown that high scores on the PCS were concurrently and prospectively associated with greater emotional distress (31. $38)$, increased disability (39-42) and more severe pain $(32,43$ 46). To date, no study has been conducted examining the relationship between pain catastrophizing and pain outcomes in francophone adolescents.

The lack of an instrument to measure psychosocial risk factors, such as pain catastrophizing, has been a serious limitation in the improvement of assessment and interventions in the French population. Considering that pain catastrophizing has been shown to be a robust factor accounting for chronic pain and disability, the modification and validation of the PCS for francophone adolescents might improve the quality of care provided to adolescents experiencing pain and disability.

In the present study, the French Canadian version of the PCS (PCS-CF) (47) was modified to make it suitable for francophone adolescents. Study 1 reports the adaptation of the adult version of the PCS-CF for use with adolescents. Study 2 presents the psychometric properties and factorial structure of the PCS for Francophone Adolescents (PCS-Ado).

\section{STUDY 1}

To develop the item phrasing of the PCS-Ado, a focus group was held comprising of experts with different competencies relevant to the psychology of pain in adolescents.

\section{Participants}

\section{METHODS}

The group of experts consisted of two clinicians who specialize in pain management and four clinical researchers. These experts were chosen on the basis of their experience in validation of questionnaires, their knowledge of methodology and their clinical experience with francophone adolescents experiencing acute, recurrent and chronic pain.

\section{Instrument}

The PCS-CF (47) had been validated with francophone adults to assess the presence and severity of pain catastrophizing. Respondents were asked to indicate on a scale of 0 (not at all) to 4 (always) the frequency they experienced each of 13 thoughts or feelings that could be experienced during a painful situation. Results of the original validation of the PCS (30) have shown a good internal consistency (Cronbach's alphas: total PCS: 0.87; rumination: 0.87 ; magnification: 0.66 ; helplessness: 0.78 ) and a good test-retest reliability $(\mathrm{r}=0.75)$. The PCS-CF demonstrated a good internal consistency (Cronbach's alphas: total PCS: 0.91; rumination: 0.87 ; magnification: 0.57 ; helplessness: 0.87 ) and a good test-retest reliability $(\mathrm{r}=0.85)$. Significant relations among anxiety, depression, pain behaviors and the PCS-CF suggest that the PCS-CF has good construct validity (47).

\section{Procedure}

A modified Delphi procedure was used to adapt the PCS-CF. Experts were asked to comment on several versions and modifications of the questionnaire. The PCS-CF (47) was used as a basis for the development of the PCS-Ado. Experts modified various components of the questionnaire (ie, instructions, formulation of some questions and format of the responses) to adapt it for adolescents aged 12 to 18 years. Subsequently, ten 12-year-old adolescents read and commented on the new questionnaire. One item was identified as difficult to understand. This item was modified and ten new 12 year-old adolescents were asked to read and comment on the modified version. No adolescent reported difficulty understanding any of the items and this version was approved by the group of experts. The final version of the PCS-Ado is available in Table 1.

\section{STUDY 2}

The principal objectives of study 2 were to assess the factorial structure of the PCS-Ado, examine the construct validity of the scale, and verify the test-retest reliability and the internal consistency of the instrument. It was expected that the factorial structure of the PCS-Ado would confirm the three-factor model proposed by Sullivan et al (30). In addition, it was expected that the PCS-Ado would show good construct validity as revealed by positive correlations among pain catastrophizing, depression, anxiety and pain. Finally, it was expected that the adapted version would show good internal consistency and high test-retest reliability.

\section{Participants}

\section{METHODS}

Three hundred forty-five participants (206 females and 139 males) were recruited from a francophone high school in Montreal, Quebec. The mean age of the sample was 14.05 $(\mathrm{SD}=1.44)$ with a range of 12 to 17 years. Students were from grades 7 to 11 .

\section{Instruments}

Sociodemographic questionnaire: To determine the characteristics of the sample, a short sociodemographic questionnaire was used. Participants were asked to indicate their age, sex, grade and language spoken at home.

Pain catastrophizing: Pain catastrophizing was assessed with the adapted version of the PCS-Ado.

Anxiety: To measure the severity of anxiety experienced by the participants, the A-trait scale of the French version of the State-Trait Anxiety Inventory $(48,49)$ was used. This scale includes 20 items assessing various anxious feelings and behaviours. On a scale of 0 (almost never) to 4 (almost always), participants were asked to indicate the frequency to which they experience each cognition, feeling or behaviour listed $(48,49)$. Depression: The French version of the Children's Depression Inventory (CDI) (50) was used to assess the presence and severity of symptoms of depression. This questionnaire includes 27 items assessing the following five dimensions: negative humour, interpersonal problems, feelings of inefficacy, 
anhedonia and low self-esteem. For each question, the adolescent selected the statement that best represented how he or she felt during the last two weeks. It has been shown that the CDI is valid and reliable with children between seven and 17 years of age (50).

Symptoms of pain: Considering that abdominal pain is one the most frequent types of recurrent pain in children and adolescents, adolescents were asked to complete an inventory of abdominal pain, using the Abdominal Pain Index (27). This instrument is a self-report measure assessing the frequency, severity and duration of (nonmenstrual) abdominal pain.

\section{Procedure}

To invite the participation of the adolescents, a research assistant met groups of students to briefly describe the nature of the study. A copy of a descriptive document and the consent form were given to the students. In addition, students were asked to give the descriptive document and consent form to their parents. Parental consent was a condition of participation. Two weeks after the initial information session, students interested in participating in the study were asked to complete the questionnaires. During the data collection, the researcher remained in the classroom and was available to answer participants' questions. Finally, 12 to 16 weeks later, participants were asked to complete the same questionnaires. Following the second administration of questionnaires, participants were debriefed.

\section{Approach to data analysis}

The factorial structure of the PCS-Ado was assessed with confirmatory factorial analysis (CFA) using Amos version 6.2 (SPSS Inc, USA). CFA is considered appropriate for confirming that a structure identified in previous research using exploratory factor analysis can be replicated in a new sample. The model fit was assessed using root mean square error of approximation (RMSEA) and the comparative fit index (CFI). A RMSEA value of 0.05 indicated a close fit. Values up to 0.08 represented reasonable errors of approximation in the population. Finally, CFI values greater than 0.90 indicated an adequate fit.

Internal consistency was assessed with Cronbach's alphas. In addition, Pearson correlations were calculated between variables to determine the construct validity and to assess the test-retest reliability. Finally, Student's $t$ tests $(\alpha=0.05)$ were conducted to examine sex differences for each of the dependent variables.

\section{RESULTS}

\section{Factorial structure of the PCS-Ado}

To test the factorial structure of the PCS-Ado, confirmatory factorial analyses were conducted. Three models were compared. Model 1 was a one-factor model, in which 13 items were indicators of a single latent factor. Model 2 was an oblique twofactor model in which the items measuring magnification and helplessness were grouped and the items measuring rumination constituted the second factor (51). Finally, the three-factor model (rumination, items 8 to 11 ; magnification, items 6,7 , 13; helplessness, items 1 to 5,12 ) proposed by Sullivan et al (30) was assessed.

Only the three-factor model showed an acceptable fit to the data (RMSEA<0.08, CFI>0.90). The goodness-of-fit measures for model 1 were: $\chi^{2}(65)=293$, RMSEA $=0.108, \mathrm{CFI}=0.844$; for model 2 were $\chi^{2}(64)=243$, RMSEA $=0.096$, CFI $=0.877$; and
TABLE 1

Pain Catastrophizing Scale for Francophone Adolescents

Pensées et réactions pendant une expérience douloureuse

Nous nous intéressons à tes pensées et réactions lorsque tu as de la douleur. Ci-dessous, il y a 13 phrases portant sur les différentes pensées et sentiments que tu peux ressentir lorsque tu as mal. Essaie de nous montrer à quelle fréquence tu as chacune de ces pensées. Encercle le mot sous chaque phrase qui reflète le mieux ton expérience avec la douleur.

1. Quand j'ai mal, je m'inquiète à savoir si la douleur va cesser Jamais Rarement Parfois Souvent Toujours

2. Quand j'ai mal, je sens que je ne pourrais plus continuer comme ça bien longtemps.

Jamais Rarement Parfois Souvent Toujours

3. Quand j'ai mal, j'ai l'impression que c'est terrible et que ça n'ira jamais mieux.

Jamais Rarement Parfois Souvent Toujours

4. Quand j'ai mal, j'ai l'impression que c'est horrible et que la douleur contrôle ma vie.

Jamais Rarement Parfois Souvent Toujours

5. Quand j'ai mal, je trouve que c'est insupportable.

Jamais Rarement Parfois Souvent Toujours

6. Quand j'ai mal, j'ai peur que la douleur empire.

Jamais Rarement Parfois Souvent Toujours

7. Quand j'ai mal, j'imagine le pire.

Jamais Rarement Parfois Souvent Toujours

8. Quand j'ai mal, je souhaite que ma douleur disparaisse.

Jamais Rarement Parfois Souvent Toujours

9. Quand j'ai mal, je suis obsédé (e) par ma douleur.

Jamais Rarement Parfois Souvent Toujours

10. Quand j'ai mal, je ne pense qu'à quel point c'est douloureux

Jamais Rarement Parfois Souvent Toujours

11. Quand j'ai mal, je ne pense qu'au fait que je voudrais que la douleur cesse.

Jamais Rarement Parfois Souvent Toujours

12. Quand j'ai mal, je pense qu'il n'y a rien que je puisse faire pour arrêter ma douleur.

Jamais Rarement Parfois Souvent Toujours

13. Quand j'ai mal, je me demande si quelque chose de grave pourrait se produire.

Jamais Rarement Parfois Souvent Toujours

for model three were $\chi^{2}(62)=183$, RMSEA $=0.081, \mathrm{CFI}=0.917$. The use of $\chi^{2}$ also showed that the three-factor model explained the data significantly better than the one-factor model $\left(\Delta \chi^{2}(3)=50, \quad \mathrm{P}<0.001\right)$ and the two-factor model $\left(\Delta \chi^{2}(2)=50, \mathrm{P}<0.001\right)$. Finally, as shown in Table 2 , items were strongly correlated. Considering that the three factors were strongly correlated, a second-order model was tested in which the three first-order factors loaded on the higher-order factor. As shown in Figure 1, with pain catastrophizing as the higher-order factor, results support the second-order model of the PCS (RMSEA=0.077, CFI=0.913).

Psychometric properties of the PCS-Ado

To test the internal consistency of the PCS-Ado, Cronbach's alphas were calculated. Results showed a good 
TABLE 2

\begin{tabular}{|c|c|c|c|c|c|c|c|c|c|c|c|c|c|}
\hline Items & 1 & 2 & 3 & 4 & 5 & 6 & 7 & 8 & 9 & 10 & 11 & 12 & 13 \\
\hline 1 & 1.00 & & & & & & & & & & & & \\
\hline 2 & $0.539^{\star}$ & 1.00 & & & & & & & & & & & \\
\hline 3 & $0.400^{*}$ & $0.557^{*}$ & 1.00 & & & & & & & & & & \\
\hline 4 & $0.346^{*}$ & $0.482^{*}$ & $0.567^{*}$ & 1.00 & & & & & & & & & \\
\hline 5 & $0.413^{*}$ & $0.493^{*}$ & $0.461^{*}$ & $0.359^{*}$ & 1.00 & & & & & & & & \\
\hline 8 & $0.172^{*}$ & 0.061 & 0.026 & 0.050 & $0.163^{*}$ & $0.253^{*}$ & 0.022 & 1.00 & & & & & \\
\hline 9 & $0.373^{*}$ & $0.508^{*}$ & $0.387^{*}$ & $0.426^{*}$ & $0.445^{*}$ & $0.371^{*}$ & $0.444^{*}$ & $0.127^{*}$ & 1.00 & & & & \\
\hline 10 & $0.373^{*}$ & $0.463^{*}$ & $0.379^{*}$ & $0.453^{*}$ & $0.479^{\star}$ & $0.370^{*}$ & $0.435^{*}$ & $0.178^{*}$ & $0.610^{*}$ & 1.00 & & & \\
\hline 11 & $0.374^{*}$ & $0.319^{*}$ & $0.290^{*}$ & $0.354^{*}$ & $0.457^{\star}$ & $0.349^{*}$ & $0.239^{*}$ & $0.359^{*}$ & $0.455^{\star}$ & $0.560^{*}$ & 1.00 & & \\
\hline 12 & $0.315^{\star}$ & $0.370^{*}$ & $0.390^{*}$ & $0.455^{*}$ & $0.318^{*}$ & $0.314^{*}$ & $0.398^{*}$ & 0.063 & $0.384^{*}$ & $0.414^{*}$ & $0.358^{*}$ & 1.00 & \\
\hline
\end{tabular}

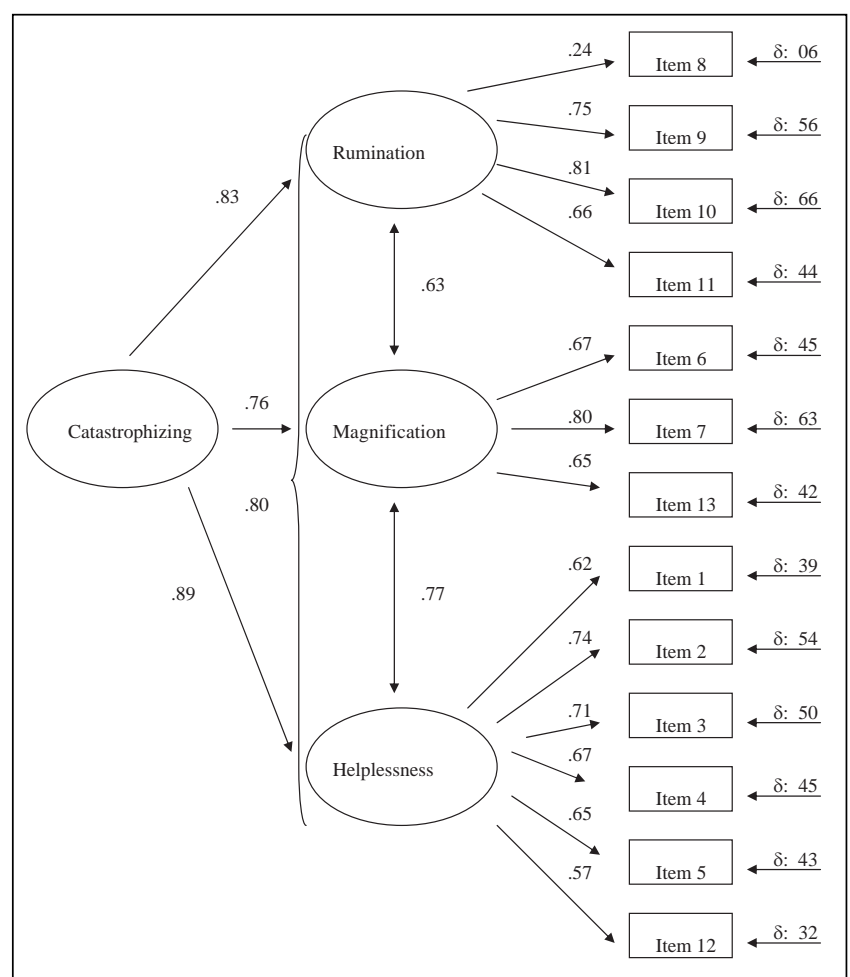

Figure 1) Factorial structure of the Pain Catastrophizing Scale for Francophone Adolescents

internal consistency for the total scale $(\mathrm{r}=0.85)$ and moderate to good consistency for the three subscales (rumination, $\mathrm{r}=0.72$; magnification, $\mathrm{r}=0.66$; helplessness, $\mathrm{r}=0.74$ ). Internal consistency was similar to the original version of the PCS.

Construct validity of the PCS-Ado was further established by examining the pattern of correlations between the total score on the PCS-Ado and the various criterion measures. Pearson correlations were performed between the scores on the PCS-Ado, the CDI and State-Trait Anxiety Inventory as well as on the Abdominal Pain Index. Consistent with previous research, correlations among these variables were significant
TABLE 3

Results of Pearson's correlations between the different outcome measures

\begin{tabular}{lcccc}
\hline Measures & PCS-Ado & CDI & STAI-T & API \\
\hline PCS-Ado & - & $0.202^{*}$ & $0.313^{*}$ & $0.379^{*}$ \\
CDI & $0.202^{*}$ & - & $0.777^{*}$ & $0.272^{*}$ \\
STAI-T & $0.313^{*}$ & $0.777^{*}$ & - & $0.349^{*}$ \\
API & $0.379^{*}$ & $0.272^{*}$ & $0.349^{*}$ & -
\end{tabular}

${ }^{*} P<0.001$. API Abdominal Pain Index; CDI Children's Depression Inventory; PCS-Ado Pain Catastrophizing Scale for Francophone Adolescents; STAI-T Trait Scale of the State-Trait Anxiety Inventory

(Table 3). As expected, individuals reporting a high level of pain catastrophizing also reported higher levels of depressive and anxious symptoms and reported increased pain. Finally, the test-retest reliability over a 12 - to 16 -week period was high $(r=0.73)$. The relative stability of the scores on the PCS-Ado suggests that it has good test-retest reliability.

Finally, sex differences in pain catastrophizing were explored using independent sample $t$ tests. As shown in Table 4, adolescent females, compared with adolescent males, reported significantly higher scores on pain catastrophizing $(\mathrm{t}(343)=5.179, \mathrm{P}<0.001)$, anxiety $(\mathrm{t}(340)=4.829, \mathrm{P}=0.001)$ as well as on intensity of pain $(\mathrm{t}(341)=6.706, \mathrm{P}<0.001)$ and depression $(\mathrm{t}(340)=2.153, \mathrm{P}=0.032)$.

\section{DISCUSSION}

The present study reports the results of the validation of an instrument to assess pain catastrophizing in francophone adolescents. The results of the study indicate that the PCS-Ado assesses the three dimensions of pain catastrophizing (ie, rumination, magnification and helplessness) reported in the original PCS and the PCS-CF $(30,47)$. The results also confirm the three-factor structure reported in the validation of the PCS for Children (English version) (45). The three-factor model adequately explained the data of the PCS-Ado and provided a better fit than the one-factor model and the two-factor model. These findings support the distinctiveness of the magnification, rumination and helplessness but also indicate that the 
three factors are dimensions of a higher-order construct.

Further evidence for the construct validity of the PCS-Ado was obtained by examining the relationship among scores on catastrophizing, depression, anxiety and pain. Results were consistent with findings previously reported in adults as well as in children. Indeed, as was expected, there was a positive correlation among catastrophizing, emotional distress and pain. These results support the construct validity of the PCS-Ado.

Reliability of the PCS-Ado was also investigated. Results showed that there was good internal consistency for the total PCS-Ado, and moderate to good consistency for the three subscales of the PCS-Ado. In addition, the results showed good test-retest reliability over a 12 - to 16 -week period. Consistent with previous research, these findings suggest that pain catastrophizing, in the absence of intervention, may represent a stable orientation to responding to pain. However, more studies will be necessary to investigate whether pain catastrophizing can best be construed as a trait variable or a situationally determined response to pain in adolescents.

Finally, as frequently reported in the literature, adolescent females reported significantly higher scores on measures of pain catastrophizing. Adolescent females also reported more anxiety and more severe pain than adolescent males. Results for the measure of depression suggest that adolescent females tend to report more depressive symptoms, but the difference between young men and young women was not significant.

There are a number of limitations to the current research that need to be considered. First, considering that results were cross-sectional, it is not possible to conclude a causal relation between pain catastrophizing, emotional distress and pain. In addition, it is not clear that adolescents' reports of abdominal pain constitute a pain condition of clinical proportion. Participants might be representative of the general population of adolescents, but no conclusion can be drawn about the validity of the PCS-Ado for adolescents in clinical settings. Considering that the discriminant validity of the PCS-Ado was not assessed, it is not possible to make statements about the unique contributions of pain catastrophizing to pain outcomes.

\section{REFERENCES}

1. Perquin CW, Hazebroek-Kampschreur AA, Hunfeld JA, van Suijlekom-Smit LW, Passchier J, van der Wouden JC. Chronic pain among children and adolescents: Physician consultation and medication use. Clin J Pain 2000;16:229-35.

2. McGrath PA, Speechley KN, Seifert CE, et al. A survey of children's acute, recurrent, and chronic pain: Validation of the pain experience interview. Pain 2000;87:59-73.

3. Abu-Arafeh I, Russell G. Prevalence and clinical features of abdominal migraine compared with those of migraine headache. Arch Dis Child 1995;72:413-7.

4. Alfvén G. The covariation of common psychosomatic symptoms among children from socio-economically differing residential areas. An epidemiological study. Acta Paediatr 1993;82:484-7.

5. Borge AI, Nordhagen R, Moe B, Botten G, Bakketeig LS. Prevalence and persistence of stomach ache and headache among children. Follow-up of a cohort of Norwegian children from 4 to 10 years of age. Acta Paediatr 1994;83:433-7.

6. Eminson M, Benjamin S, Shortall A, Woods T, Faragher B. Physical symptoms and illness attitudes in adolescents: An epidemiological study. J Child Psychol Psychiatry 1996;37:519-28.

7. Faull C, Nicol AR. Abdominal pain in six-year-olds: An epidemiological study in a new town. J Child Psychol Psychiatry 1986;27:251-60.

8. Garber J, Walker LS, Zeman J. Somatization symptoms in a community sample of children and adolescents: Further validation of the Children's Somatization Inventory. Psychol Assess 1991;3:588-95.
TABLE 4

\begin{tabular}{lcrcc}
\multicolumn{4}{l}{ Sex differences in the scores on the outcome measures } \\
\hline Sex & PCS-Ado & CDI & STAI-T & API \\
\hline Female & $24.53(7.79)$ & $10.36(6.309)$ & $40.82(9.714)$ & $5.32(2.815)$ \\
Male & $19.65(7.75)$ & $8.87(6.237)$ & $35.96(8.202)$ & $3.20(2.955)$ \\
Total & $22.56(8.13)$ & $9.76(6.313)$ & $38.86(9.429)$ & $4.47(3.057)$
\end{tabular}

API Abdominal Pain Index; CDI Children's Depression Inventory; PCS-Ado Pain Catastrophizing Scale for Francophone Adolescents; STAI-T Trait Scale of the State-Trait Anxiety Inventory

Finally, many factors that may mediate or moderate the relationship between catastrophizing, anxiety, depression and pain were not investigated.

Despite these limitations, the PCS-Ado may have important theoretical and clinical implications. The availability of a valid and reliable measure to assess pain catastrophizing in francophone adolescents may foster psychosocial research with francophone adolescents suffering from acute, recurrent and chronic pain. The availability of the PCS-Ado may promote the development of new research initiatives on the development of treatment approaches for pain and disability experienced by francophone adolescents.

Finally, from a clinical perspective, the development of the PCS-Ado may help psychologists and other health professionals evaluate psychological risk factors for chronic pain and disability in adolescents. In addition, the PCS-Ado may also be used to educate the adolescents, parents and health professionals about the risk factors for pain and disability.

ACKNOWLEDGEMENT: The authors wish to thank the administration, parents, teachers and students of the Collège Beaubois for their participation and the Regroupement provincial de recherche en adaptation-réadaptation (REPAR) for their financial support.

FINANCIAL SUPPORT: This study was supported by the Regroupement provincial de recherche en adaptation-réadaptation (REPAR)

9. Hyams JS, Burke G, Davis PM, Rzepski B, Andrulonis PA Abdominal pain and irritable bowel syndrome in adolescents: A community-based study. J Pediatr 1996;129:220-6.

10. Mortimer M, Kay J, Jaron A, Good PA. Does a history of maternal migraine or depression predispose children to headache and stomachache? Headache 1992;32:353-5.

11. Grøholt EK, Stigum H, Nordhagen R, Köhler L. Recurrent pain in children, socio-economic factors and accumulation in families. Eur J Epidemiol 2003;18:965-75.

12. Hunfeld JA, Perquin CW, Bertina W, et al. Stability of pain parameters and pain-related quality of life in adolescents with persistent pain: A three-year follow-up. Clin J Pain 2002;18:99-106.

13. Smedbråten BK, Natvig B, Rutle O, Bruusgaard D. Selfreported bodily pain in schoolchildren. Scand J Rheumatol 1998;27:273-6

14. Taimela S, Kujala UM, Salminen JJ, Viljanen T. The prevalence of low back pain among children and adolescents. A nationwide, cohort-based questionnaire survey in Finland. Spine 1997;22:1132-6.

15. Goodman JE, McGrath PJ. The epidemiology of pain in children and adolescents: A review. Pain 1991;46:247-64.

16. Guidetti V, Galli F. Evolution of headache in childhood and adolescence: An 8-year follow-up. Cephalalgia 1998;18:449-54.

17. Perquin CW, Hunfeld JA, Hazebroek-Kampschreur AA, et al. Insights in the use of health care services in chronic benign pain in childhood and adolescence. Pain 2001;94:205-13.

18. Sleed M, Eccleston C, Beecham J, Knapp M, Jordan A. The economic impact of chronic pain in adolescence: Methodological 
considerations and a preliminary costs-of-illness study. Pain 2005;119:183-90.

19. Campo JV, Bridge J, Ehmann M, et al. Recurrent abdominal pain, anxiety and depression in primary care. Pediatrics 2004;113:817-24.

20. Campo JV, Comer DM, Jansen-Mcwilliams L, Gardner W, Kelleher KJ. Recurrent pain, emotional distress and health service use in childhood. J Pediatr 2002;141:76-83.

21. Chalkiadis GA. Management of chronic pain in children. Med J Austr 2001;175:476-9.

22. Garber J, Zeman J, Walker LS. Recurrent abdominal pain in children: Psychiatric diagnoses and parental psychopathology. J Am Acad Child Adolesc Psychiatry 1990;29:648-56.

23. Gil KM, Thompson RJ Jr, Keith BR, Tota-Faucette M, Noll S, Kinney TR. Sickle cell disease pain in children and adolescents: Change in pain frequency and coping strategies over time. J Pediatr Psychol 1993;18:621-37.

24. Kashikar-Zuck S, Goldschneider KR, Powers SW, Vaught MH, Hershey AD. Depression and functional disability in chronic pediatric pain. Clin J Pain 2001;17:341-9.

25. Robinson JO, Alverez JH, Dodge JA. Life events and family history in children with recurrent abdominal pain. J Psychosom Res 1990;34:171-81.

26. Roth-Isigkeit A, Thyen U, Stöven H, Schwarzenberger J, Schmucker P. Pain among children and adolescents: Restrictions in daily living and triggering factors. Pediatrics 2005;115:152-62.

27. Walker LS, Greene JW. Children with recurrent abdominal pain and their parents: More somatic complaints, anxiety and depression than other patient families? J Pediatr Psychol $1989 ; 14: 231-43$.

28. Hunfeld JA, Perquin CW, Duivenvoorden HJ, et al. Chronic pain and its impact on quality of life in adolescents and their families. J Pediatr Psychol 2001;26:145-53.

29. Sullivan MJ, Thorn B, Haythornthwaite JA, et al. Theoretical perspectives on the relation between catastrophizing and pain. Clin J Pain 2001;17:52-64.

30. Sullivan MJL, Bishop SR, Pivik J. The Pain Catastrophizing Scale: Development and validation. Psychol Assess 1995;7:524-32.

31. Geisser ME, Robinson ME, Keefe FJ, Weiner ML. Catastrophizing, depression and the sensory, affective and evaluative aspects of chronic pain. Pain 1994;59:79-83.

32. Geisser ME, Robinson ME, Riley JL II. Pain beliefs, coping and adjustment to chronic pain: Let's focus more on the negative. Pain Forum 1999;8:161-8.

33. Jensen MP, Turner JA, Romano JM, Karoly P. Coping with chronic pain: A critical review of the literature. Pain 1991;47:249-83.

34. Kuch K, Cox B, Evans RJ, Watson PC, Bubela C. To what extent do anxiety and depression interact with chronic pain? Can J Psychiatry 1993;38:36-8.

35. Sullivan MJL, Neish N. The effects of disclosure on pain during dental hygiene treatment: The moderating role of catastrophizing. Pain 1999;79:155-63.
36. Sullivan MJ, D'Eon JL. Relation between catastrophizing and depression in chronic pain patients. J Abnorm Psychol 1990;99:260-3.

37. Sullivan MJ, Rodgers WM, Kirsch I. Catastrophizing, depression and expectancies for pain and emotional distress. Pain 2001;91:147-54.

38. Turner JA, Jensen MP, Warms CA, Cardenas DD. Catastrophizing is associated with pain intensity, psychological distress, and painrelated disability among individuals with chronic pain after spinal cord injury. Pain 2002;98:127-34.

39. Holzberg AD, Robinson ME, Geisser ME, Gremillion HA. The effects of depression and chronic pain on psychosocial and physical functioning. Clin J Pain 1996;12:118-25.

40. Sullivan MJ, Rodgers WM, Wilson PM, Bell GJ, Murray TC, Fraser SN. An experimental investigation of the relation between catastrophizing and activity intolerance. Pain 2002;100:47-53.

41. Sullivan MJ, Stanish W, Waite H, Sullivan M, Tripp DA. Catastrophizing, pain and disability in patients with soft-tissue injuries. Pain 1998;77:253-60.

42. Vienneau TL, Clark AJ, Lynch ME, Sullivan MJL. Catastrophizing, functional disability and pain reports in adults with chronic low back pain. Pain Res Manag 1999;4:93-6.

43. Bennett-Branson SM, Craig KD. Postoperative pain in children: Developmental and family influences on spontaneous coping strategies. Can J Behaviour Science 1993;25:355-83.

44. Brown JM, O’Keeffe J, Sanders SH, Baker B. Developmental changes in children's cognition to stressful and painful situations. J Pediatr Psychol 1986,11:343-57.

45. Crombez G, Bijttebier P, Eccleston C, et al. The child version of the pain catastrophizing scale (PCS-C): A preliminary validation. Pain 2003;104:639-46.

46. Garnefski N, Legerstee J, Kraaij VV, Van Den Kommer T, Teerds J. Cognitive coping strategies and symptoms of depression and anxiety: A comparison between adolescents and adults. J Adolesc 2002;25:603-11.

47. French DJ, Noël M, Vigneau F, French JA, Cyr CP, Evans RT. PCSCF: A French-language, French-Canadian adaptation of the Pain Catastrophizing Scale. Can J Behaviour Science 2005;37:181-92.

48. Gauthier J, Bouchard S. Adaptation canadienne-française de la forme révisée du State-Trait Anxiety Inventory de Spielberger. Can J Behaviour Science 1993;25:559-78.

49. Spielberger CD, Gorusch RL, Lushene RE. Manual for the StateTrait Anxiety Inventory. Palo Alto: Consulting Psychologists Press, 1970.

50. Kovacs M. Children's Depression Inventory (CDI): Manual. Toronto: Multi-Health Systems Inc, 1992.

51. Osman A, Barrios FX, Kopper BA, Hauptmann W, Jones J, O'Neill E. Factor structure, reliability, and validity of the Pain Catastrophizing Scale. J Behav Med 1997;20:589-605. 


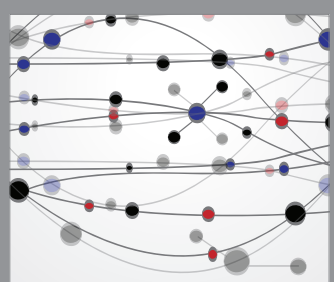

The Scientific World Journal
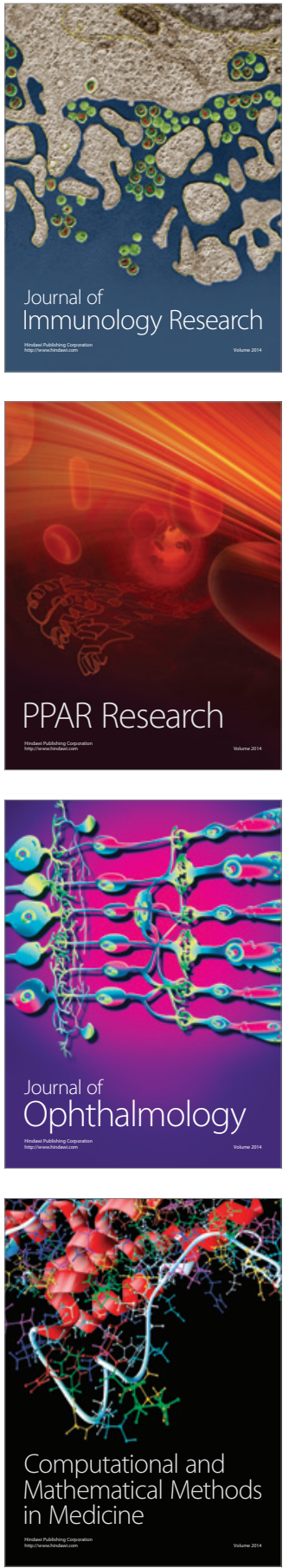

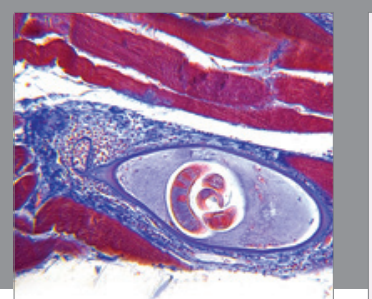

Gastroenterology Research and Practice

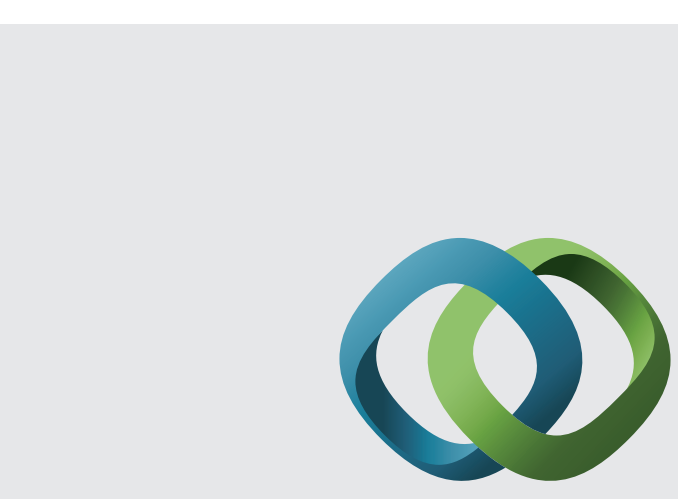

\section{Hindawi}

Submit your manuscripts at

http://www.hindawi.com
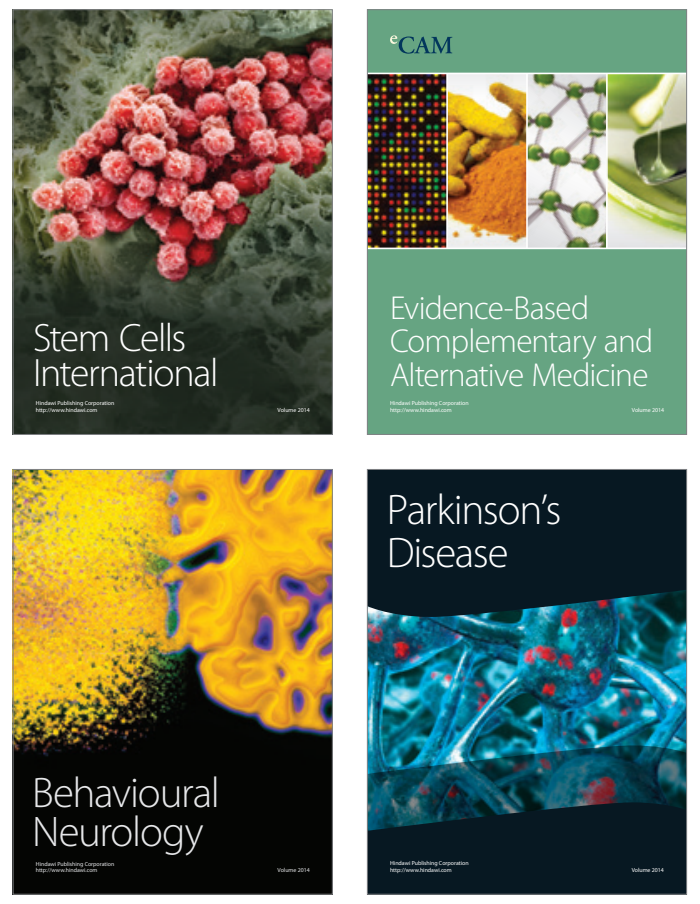
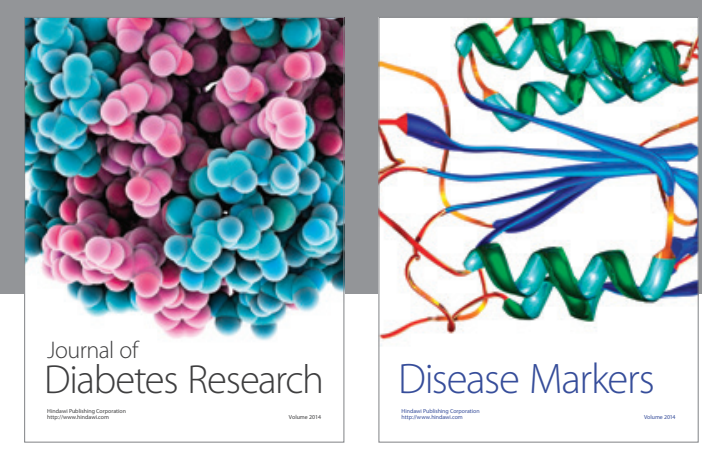

Disease Markers
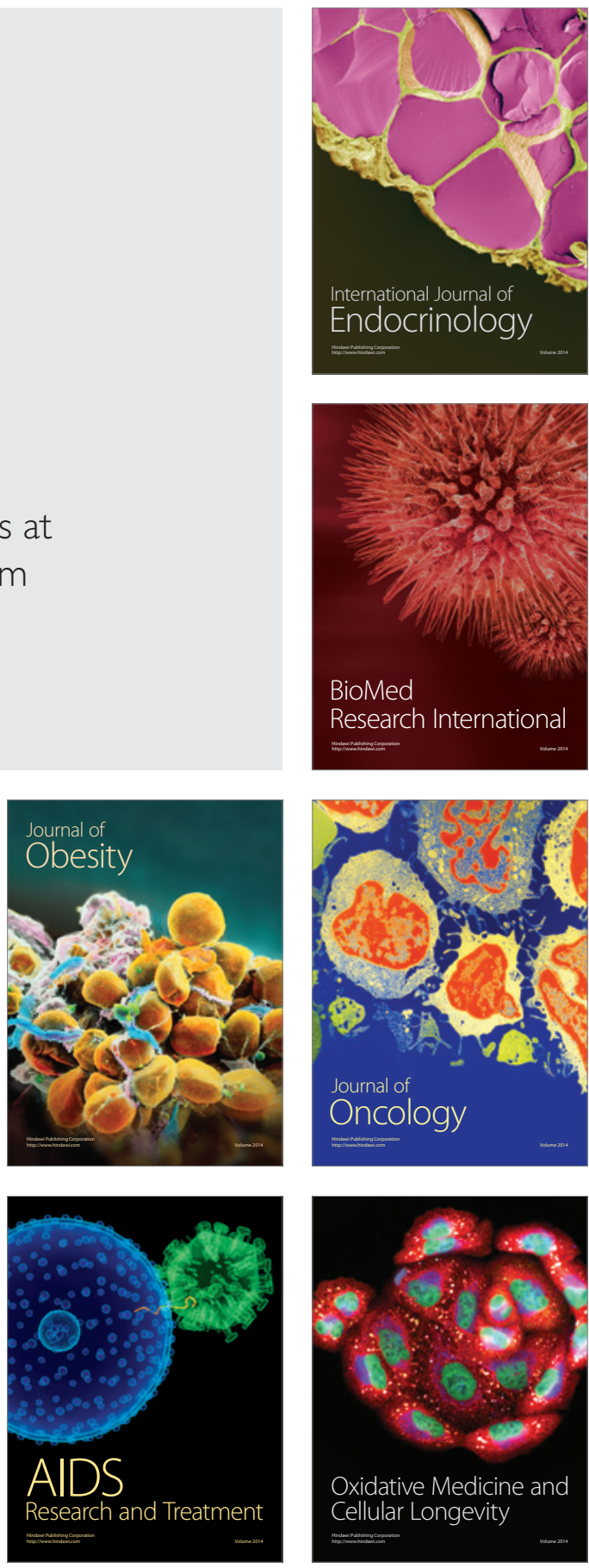